Bull. Chem. Soc. Ethiop. 2013, 27(3), 427-437.

Printed in Ethiopia

ISSN 1011-3924

DOI: http://dx.doi.org/10.4314/bcse.v27i3.12

(c) 2013 Chemical Society of Ethiopia

\title{
A SIMPLE AND EFFICIENT APPROACH FOR SYNTHESIS OF 1,4-DIHYDRO- PYRIDINES USING NANO-CRYSTALLINE SOLID ACID CATALYST
}

\author{
Abbas Teimouri ${ }^{1, *}$, Leila Ghorbanian ${ }^{2}$ and Athar Moatari ${ }^{1}$ \\ ${ }^{1}$ Chemistry Department, Payame Noor University, 19395-4697, Tehran, Iran \\ ${ }^{2}$ Materials Engineering Department, Isfahan University of Technology, Isfahan, Iran
}

(Received October 22, 2012; revised December 31, 2012)

\begin{abstract}
A simple highly versatile and efficient synthesis of various 1,4-dihydropyridines in the condensation of aromatic aldehydes with $\beta$-dicarbonyl compounds and ammonium acetate in the presence of nano-sulfated zirconia, nano-structured $\mathrm{ZnO}$, nano- $\gamma$-alumina and nano-ZSM-5 zeolites, as catalyst in the ethanol at moderate temperature is presented. The advantages of method are short reaction times and milder conditions and easy work-up. The catalysts can be recovered for the subsequent reactions and reused without any appreciable loss of efficiency.
\end{abstract}

KEY WORDS: Nano-sulfated zirconia, Nano-sized ZnO, Nano- $\gamma$-alumina, Nano-ZSM-5 zeolites, Green synthesis, 1,4-Dihydropyridines

\section{INTRODUCTION}

1,4-Dihydropyridines (1,4-DHPs) are important class of compounds in the field of drugs and pharmaceuticals [1]. The DHP heterocyclic rings are a common feature of various bioactive compounds such as anticonvulsant, antidiabatic, antianxiety, antidepressive, antitumor, analgesic, seditative, vasodilator, bronchodilator, hypnotic, and anti-inflammatory agents [2].

DHPs exhibit significant biological activities in the treatment of cardiovascular disease as calcium channel blockers [3]. They also present vasodilating activity [4], and are NADH mimics [5]. Various clinically used cardiovascular agents $[6,7]$ such as nifedipine, nicardipine, amlodipine and other related derivatives are dihydropyridyl compounds effective in the treatment of hypertension. 1,4-Dihydropyridine derivatives possess a variety of biological activities such as HIV protease inhibition $[8,9]$.

Some representatives like nifedipine, niguldipine, nicardipine and amlodipine are widely used for treatment of hypertension [10]. In addition to acting as cerebral antiischemic agents in the treatment of Alzheimer's disease [11], They also act as chemo sensitizers in tumor therapy [12]. 1,4-DHPs are generally synthesised by classical Hantzsch method, which involves cyclocondensation of an aldehyde, $\beta$-ketoesters and ammonia either in acetic acid or by refluxing in ethanol. However, the yield of 1,4-DHP obtained by Hantzsch method is generally low [13-15]. Various methods for the synthesis of dihydropyridine derivatives are described in the literature including condensation of aromatic aldehydes, $\beta$-dicarbonyl compounds and ammonium acetate using of microwave [16], ionic liquids [17], tetrabutylammonium hydrogen sulfate [18], silica gel/ $\mathrm{NaHSO}_{4}$ [19], $\mathrm{AlCl}_{3} \cdot 6 \mathrm{H}_{2} \mathrm{O}$ [20], TMSI [21], triphenylphosphine [22], $\mathrm{InCl}_{3}$ [23], $\mathrm{I}_{2}$ [24], cellulose sulfuric acid [25], alumina sulfuric acid [26], $\mathrm{SiO}_{2} / \mathrm{HClO}_{4}$ [27], metal triflate [28], $\mathrm{Fe}\left(\mathrm{CF}_{3} \mathrm{CO}_{2}\right)_{3}$ [29], nano $\mathrm{CuO}$ [30], nano $\mathrm{MgO}$ [31], ultrasound irradiation [32], solvent free [33], and aqueous media [34].

Recently, $\mathrm{La}_{2} \mathrm{O}_{3}$ [35], Y(OTf $)_{3}$ [36], and silica sulfuric acid [37] have been employed for this condensation reaction. Some of these methods include long reaction time, harsh reaction conditions, low product yields, occurrence of several side products, difficulty in recovery and

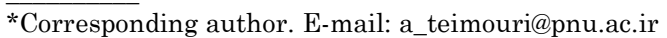


reusability of the catalysts and the use of large quantity of volatile organic solvents. Due to these problems, development of an efficient and versatile method for the preparation of Hantzsch 1,4DHPs is an active ongoing research area and there is scope for further improvements towards mild reaction conditions and improved yields.

In the recent years, the use of nano-structured $\mathrm{ZnO}$ [38], nano-sulfated zirconia [39], nano- $\gamma$ alumina [40], and nano-ZSM-5 zeolite [41], catalysts has received considerable interest in organic synthesis. This extensive application of heterogeneous catalysts in synthetic organic chemistry can make the synthetic process more efficient from both environmental and economic point of view [42] and used-catalyst can be easily recycled.

Very recently we have developed a convenient and efficient procedure for the synthesis of 2,4,5-trisubstituted imidazoles using clays, zeolite, nano-crystalline sulfated zirconia (SZ) as catalyst [43]. Herein, we report an efficient process for the preparation of 1,4-DHPs derivatives from various aldehydes, $\beta$-dicarbonyl compounds and ammonium acetate catalyzed by heterogeneous solid acid catalysts including using nano-structured $\mathrm{ZnO}$, nano-sulfated zirconia, nano- $\gamma$-alumina and nano-ZSM-5 zeolites, as the catalyst in ethanol at moderate temperature.

\section{RESULTS AND DISCUSSION}

In the reaction between aromatic aldehydes, $\beta$-keto esters, and ammonium acetate in the presence nano-structured $\mathrm{ZnO}$, nano-sulfated zirconia, nano- $\gamma$-alumina and nano-ZSM-5 zeolites, as the catalyst effect of the catalyst amount was investigated (Table 1). To minimize the formation of by-products and to achieve good yields of the desired products, the reaction was optimized by varying the amount of catalyst. The results showed that nano-crystalline sulfated zirconia (SZ) promoted the reaction more effectively than nano-structured $\mathrm{ZnO}$, nano- $\gamma$-alumina and nano-ZSM-5 zeolites as far as the amount of catalyst and reaction time are concerned (Table 2).

In a systematic study, ethyl acetoacetate was added to a solution of benzaldehyde, $\mathrm{NH}_{4} \mathrm{OAc}$ and catalyst in ethanol and the reaction mixture was stirred at room temperature. Our initial experiments focused on the optimization of the amount of catalysts by using 1 equiv of benzaldehyde, 2 equiv of ethyl acetoacetate, 1.5 equiv of $\mathrm{NH}_{4} \mathrm{OAc}$ and variable amount of catalysts. In an initial endeavor, a blank reaction was carried out using each of ethyl acetoacetate, benzaldehyde, and $\mathrm{NH}_{4} \mathrm{OAc}$ without catalyst. These were stirred at room temperature in ethanol. In the absence of catalyst, after $24 \mathrm{~h}$ no product was obtained. To further improve the yield and to optimize the reaction conditions, the same reaction was carried out in the presence of $(10 \mathrm{~mol} \%)$ of catalyst under similar conditions. A tremendous improvement was observed and the yield of product was dramatically increased up to $95 \%$ after stirring the mixture for only $45 \mathrm{~min}$.

To minimize the formation of by-products and to achieve good yield of the desired product, the reaction was optimized by varying the amount of catalyst $(5,10$ and $15 \mathrm{mg})$, an increase in the amount of nano SZ from 5 to $10 \mathrm{mg}$ increased the yield of the desired product to a great extent (85-92\%, Table 1, entries 2-4). The percentage yield of the product with 5, 10 and 15 $\mathrm{mol} \%$ of nano- $\mathrm{ZnO}$ as a catalyst are $77 \%, 79 \%$ and $75 \%$, respectively (Table 1, entries 5-7). For the nano- $\gamma$-alumina and nano-ZMS- 5 as the catalyst, when the catalyst content was increased to $15 \mathrm{mg}$, the product yield decreased to $76 \%$ (Table 1, entry 10) and $80 \%$ (Table 2, entry 13), respectively.

Next, we examined the scope of the reaction by using various aryl aldehydes. Various aldehydes bearing different substitutes, such as para-Me, $\mathrm{MeO}, \mathrm{OH}, \mathrm{Cl}$, and $\mathrm{NO}_{2}$ on the aryl rings were all suitable to the reaction. The activity of aldehydes with electron-withdrawing group such as 4-nitrobenzaldehyde and 4-cholorobenzaldehyde is higher than that with electron- 
donating groups such as 4-methoxybenzaldehyde, 4-methylbenzaldehyde and 4-hydroxybenzaldehyde (Table 2, entries 1-6).

Table 1. Reaction of benzaldehyde, ethyl acetoacetateand $\mathrm{NH}_{4} \mathrm{OAc}$ catalyzed by different catalysts.

\begin{tabular}{|c|c|c|c|c|}
\hline Entry & Catalyst & Catalyst loading & Time $(\mathrm{min})$ & ${\text { Yield }(\%)^{\mathrm{a}}}^{\mathrm{a}}$ \\
\hline 1 & None & - & 24 & - \\
\hline 2 & Nano-SZ & $5(\mathrm{mg})$ & 50 & 87 \\
\hline 3 & Nano-SZ & $10(\mathrm{mg})$ & 40 & 92 \\
\hline 4 & Nano-SZ & $15(\mathrm{mg})$ & 45 & 85 \\
\hline 5 & Nano-ZnO & $5(\mathrm{~mol} \%)$ & 40 & 77 \\
\hline 6 & Nano-ZnO & $10(\mathrm{~mol} \%)$ & 45 & 79 \\
\hline 7 & Nano-ZnO & $15(\mathrm{~mol} \%)$ & 55 & 75 \\
\hline 8 & Nano- $\gamma$-alumina & $5(\mathrm{mg})$ & 50 & 78 \\
\hline 9 & Nano- - -alumina & $10(\mathrm{mg})$ & 40 & 80 \\
\hline 10 & Nano- $\gamma$-alumina & $15(\mathrm{mg})$ & 60 & 76 \\
\hline 11 & Nano-ZMS-5 & $5(\mathrm{mg})$ & 40 & 82 \\
\hline 12 & Nano-ZMS-5 & $10(\mathrm{mg})$ & 45 & 85 \\
\hline 13 & Nano-ZMS-5 & $15(\mathrm{mg})$ & 55 & 80 \\
\hline
\end{tabular}

${ }^{a}$ Yields after isolation of products.

Table 2. Acid-catalzed synthesis of 1,4-dihydropyridines derivatives ${ }^{\mathrm{a}}$.

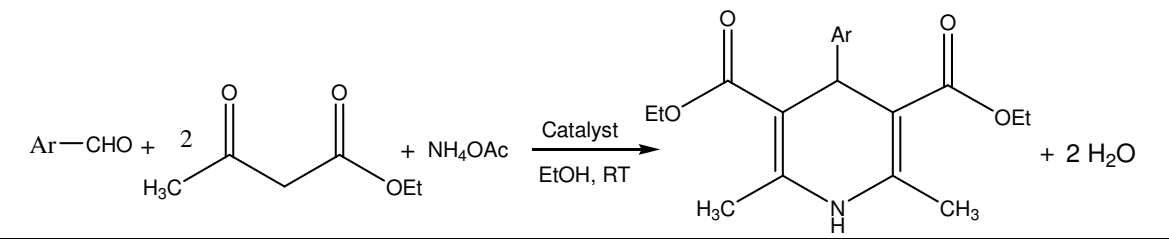

\begin{tabular}{|c|c|c|c|c|c|c|c|}
\hline Entry & Product & $\mathrm{Ar}$ & \multicolumn{4}{|c|}{ Time (min)/Yield (\%) } & \multirow{2}{*}{ m.p. ${ }^{\circ} \mathrm{C}$ (lit.) [Ref.] } \\
\cline { 4 - 7 } & & $\begin{array}{c}\text { Nano- } \\
\text { ZnO }\end{array}$ & $\begin{array}{c}\text { Nano- } \gamma- \\
\text { alumina }\end{array}$ & $\begin{array}{c}\text { Nano- } \\
\text { ZMS-5 }\end{array}$ & $\begin{array}{c}\text { Nano- } \\
\text { crystalline SZ }\end{array}$ & \\
\hline 1 & $\mathbf{1 a}$ & $\mathrm{C}_{6} \mathrm{H}_{5}$ & $45 / 79$ & $40 / 80$ & $45 / 85$ & $40 / 92$ & $150-152(152-154)[44]$ \\
\hline 2 & $\mathbf{1 b}$ & $4-\mathrm{ClC}_{6} \mathrm{H}_{5}$ & $50 / 83$ & $50 / 85$ & $55 / 90$ & $50 / 94$ & $142-144(145-146)[44]$ \\
\hline 3 & $\mathbf{1 c}$ & $4-\mathrm{NO}_{2} \mathrm{C}_{6} \mathrm{H}_{5}$ & $45 / 72$ & $45 / 70$ & $50 / 75$ & $45 / 80$ & $164-166$ \\
\hline 4 & $\mathbf{1 d}$ & $4-\mathrm{OHC}_{6} \mathrm{H}_{5}$ & $45 / 78$ & $40 / 75$ & $45 / 80$ & $40 / 85$ & $226-228(229-231)[44]$ \\
\hline 5 & $\mathbf{1 e}$ & $4-\mathrm{CH}_{3} \mathrm{C}_{6} \mathrm{H}_{5}$ & $50 / 81$ & $45 / 80$ & $40 / 85$ & $50 / 90$ & $162-164$ \\
\hline 6 & $\mathbf{1 f}$ & $4-\mathrm{OCH}_{3} \mathrm{C}_{6} \mathrm{H}_{5}$ & $45 / 80$ & $50 / 79$ & $55 / 86$ & $60 / 92$ & $152-154(154-156)[44]$ \\
\hline 7 & $\mathbf{1 g}$ & $3-\mathrm{NO}_{2} \mathrm{C}_{6} \mathrm{H}_{5}$ & $45 / 75$ & $45 / 78$ & $50 / 85$ & $45 / 88$ & $164-166(161-163)[17]$ \\
\hline 8 & $\mathbf{1 h}$ & $3-\mathrm{OHC}_{6} \mathrm{H}_{5}$ & $48 / 74$ & $40 / 80$ & $45 / 86$ & $50 / 90$ & $178-180(180-182)[34]$ \\
\hline 9 & $\mathbf{1 i}$ & $2-\mathrm{ClC}_{6} \mathrm{H}_{5}$ & $50 / 74$ & $45 / 80$ & $40 / 86$ & $45 / 92$ & $80-82(83-85)[45]$ \\
\hline 10 & $\mathbf{1 j}$ & $4-\mathrm{BrC}_{6} \mathrm{H}_{5}$ & $45 / 72$ & $50 / 78$ & $45 / 84$ & $50 / 90$ & $158-160(162-164)[22]$ \\
\hline
\end{tabular}

Table 3 compares the efficiency of present method with the efficiency of other methods in the synthesis of 1,4-dihydropyridines, respectively. As can be seen SZ shows better efficiency than other method.

In order to optimize the reaction conditions, including solvents and temperature, the reaction of benzaldehyde, ethyl acetoacetate and ammonium acetate was optimized by time of the reaction and using various solvents such as $\mathrm{H}_{2} \mathrm{O}, \mathrm{EtOH}, \mathrm{MeOH}, \mathrm{CH}_{3} \mathrm{CN}, \mathrm{DCM}$ and toluene. (Table 4, entries 1-6). Acetonitrile and ethanol provided excellent yields and proved to be the solvent of choice, whereas reaction in toluene and dichloromethane (DCM) solvent gave low product yields even after $70 \mathrm{~min}$ and $65 \mathrm{~min}$ (Table 4, entries 5 and 6). The best results were 
obtained when the reaction was carried out in the ethanol in the presence of catalyst (Table 4, entry 2). Although water is a desirable solvent for chemical reactions for reasons of cost, safety and environmental concerns, we found that using water in this reaction gave moderate yields of products under reflux condition after long reaction times.

Table 3. Comparison of the efficiency of nano-crystalline SZ with other reported catalysts in the synthesis of 1,4-dihydropyridines derivatives ${ }^{\mathrm{a}}$.

\begin{tabular}{|c|c|c|c|c|c|}
\hline Entry & Catalyst (mol \%) & Condition & Time & Yield $(\%)^{\mathrm{a}}$ & References \\
\hline 1 & Nano-crystalline SZ & $\mathrm{EtOH} / \mathrm{RT}$ & $40 \mathrm{~min}$ & 92 & This work \\
\hline 2 & Nano-ZMS-5 & EtOH/RT & $45 \mathrm{~min}$ & 85 & This work \\
\hline 3 & Nano- $\gamma$-alumina & EtOH/RT & $40 \mathrm{~min}$ & 80 & This work \\
\hline 4 & Nano-ZnO & $\mathrm{EtOH} / \mathrm{RT}$ & $45 \mathrm{~min}$ & 79 & This work \\
\hline 5 & Nano $\mathrm{CuO}$ & EtOH/RT & $6 \mathrm{~h}$ & 60 & {$[30]$} \\
\hline 6 & Alumina sulfuric acid & $\mathrm{CH}_{3} \mathrm{OH} / 70^{\circ}$ & $5 \mathrm{~h}$ & 87 & [26] \\
\hline 7 & {$\left[\mathrm{PSIM}\left(\mathrm{CH}_{2}\right)_{4} \mathrm{SO}_{3} \mathrm{H}\right]\left[\mathrm{HSO}_{4}\right]$} & Ethanol/reflux & $3.5 \mathrm{~h}$ & 80 & [17] \\
\hline 8 & Ammonium carbonate & $\mathrm{H}_{2} \mathrm{O} / 55-60^{\circ}$ & $4 \mathrm{~h}$ & 92 & [34] \\
\hline 9 & $\mathrm{AlCl}_{3} 6 \mathrm{H}_{2} \mathrm{O}$ & Solvent free $/ 60^{\circ}$ & $1 \mathrm{~h}$ & 83 & [20] \\
\hline 10 & Organocatalyst & Solvent free/RT & $1 \mathrm{~h}$ & 90 & [41] \\
\hline 11 & Silica gel/NaHSO ${ }_{4}$ & $\mathrm{CH}_{3} \mathrm{CN} / \mathrm{RT}$ & $6 \mathrm{~h}$ & 85 & [19] \\
\hline 12 & $\mathrm{PPh}_{3}$ & EtOH/reflux & $5 \mathrm{~h}$ & 72 & {$[22]$} \\
\hline
\end{tabular}

Banzaldehyde, ethyl acetoacetate, and ammonium acetate were taken in 1:2:1.5 ratio in presence of catalyst.

Table 4. Effect of solvent on the reaction times and yields.

\begin{tabular}{|l|l|l|l|}
\hline Entry & Solvent & Time $(\min )$ & ${\text { Yield }(\%)^{\mathrm{a}}}^{(2}$ \\
\hline 1 & $\mathrm{H}_{2} \mathrm{O}$ & 60 & 45 \\
\hline 2 & $\mathrm{EtOH}$ & 50 & 92 \\
\hline 3 & $\mathrm{MeOH}$ & 70 & 75 \\
\hline 4 & $\mathrm{CH}_{3} \mathrm{CN}$ & 50 & 80 \\
\hline 5 & DCM & 65 & 65 \\
\hline 6 & Toluene & 70 & 60 \\
\hline
\end{tabular}

Aromatic aldehydes $(1.0 \mathrm{mmol}), \beta$-keto esters $(2.0 \mathrm{mmol})$ and ammonium acetate $(1.5 \mathrm{mmol})$ in the presence of catalyst under reflux condition in various solvents.

One of the most important advantages of heterogeneous catalysis over the homogeneous counterpart is the possibility of reusing the catalyst by simple filtration, without loss of activity. The recovery and reusability of the catalyst was investigated in the product formation. After completion of the reaction, the catalyst was separated by filtration, washed 3 times with $5 \mathrm{~mL}$ acetone, then with doubly distilled water several times and dried at $110{ }^{\circ} \mathrm{C}$. Then the recovered catalyst was used in the next run. Then the recovered catalyst was used in the next run. The results of three consecutive runs showed that the catalyst can be reused several times without significant loss of its activity (Figure 1).

According to the mechanism suggested on the basis of literature [25], we propose a mechanism for the formation of 1,4-DHP 1a-j (Figure 2), the first step of this reaction can be visualized as proceeding through a Knoevenagel condensation product as a key intermediate. A second key intermediate is an ester enamine, which is produced by condensation of the second equivalent of the $\beta$-ketoester with ammonium acetate. Further condensation between the two fragments gives the 1,4-DHPs derivatives. 


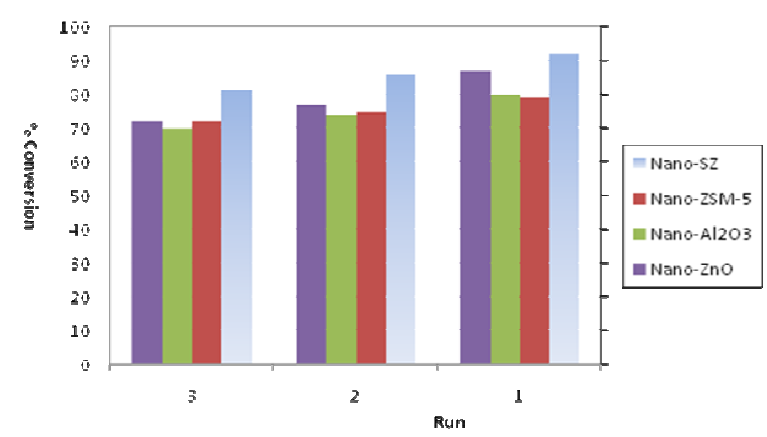

Figure 1. The results obtained from catalyst reuse in the product formation.

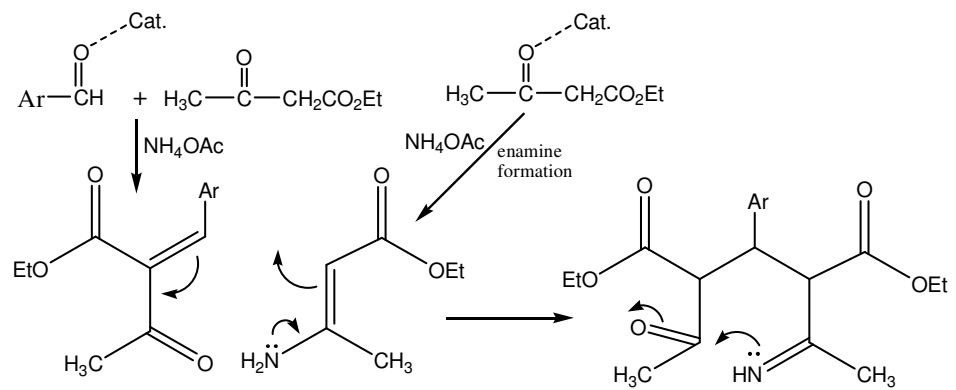

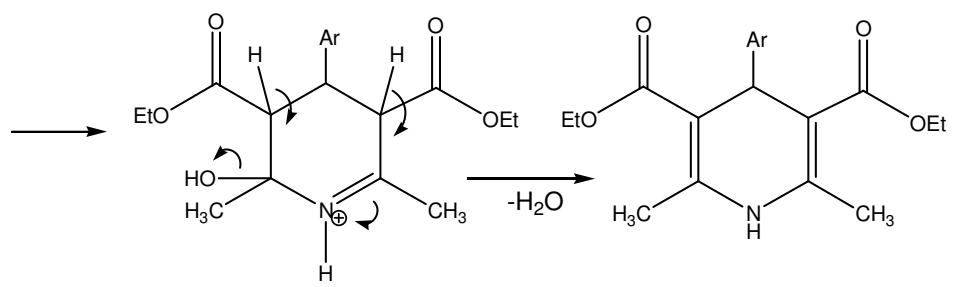

Figure 2. Proposed mechanism for one-pot synthesis of 1,4-DHPs derivatives.

\section{CONCLUSIONS}

We have demonstrated an efficient, versatile and convenient method for the synthesis of 1,4dihydropyridines through the three components coupling of aldehydes, $\beta$-keto ester and using nano-sulfated zirconia, nano-structured $\mathrm{ZnO}$, nano- $\gamma$-alumina and nano-ZSM-5 zeolites with the nano-sulfated zirconia exhibiting greater activity has also been demonstrated. Compared to previously reported methods, the mild reaction conditions, high yields, short reaction time, easy work-up, clean reaction profiles, lower catalyst loading and cost efficiency render this approach as an interesting alternative to the existing methods.

\section{EXPERIMENTAL}

All the reagents were purchased from Merck and Aldrich and used without further purification. Products were characterized by spectroscopy data (IR, FTIR, ${ }^{1} \mathrm{H}$ NMR and ${ }^{13} \mathrm{C}$ NMR spectra), 
elemental analysis (CHN) and melting points. A JASCO FT/IR-680 PLUS spectrometer was used to record IR spectra using $\mathrm{KBr}$ pellets. NMR spectra were recorded on a Bruker 400 Ultrasheild NMR and DMSO- $\mathrm{d}_{6}$ was used as solvent. Melting points reported were determined by open capillary method using a Galen Kamp melting point apparatus and are uncorrected. Mass spectra were recorded on a Shimadzu Gas Chromatograph Mass Spectrometer GCMSQP5050A/Q P5000 apparatus.

\section{Catalyst preparation}

Synthesis of nano-crystalline sulfated zirconia. Nano-crystalline sulfated zirconia was prepared by one step sol-gel technique [46]. A typical synthesis involves the addition of concentrated sulfuric acid $(1.02 \mathrm{~mL})$ to zirconium $n$-propoxide precursor $(30 \mathrm{wt} \%)$ followed by the hydrolysis with water. After $3 \mathrm{~h}$ aging at room temperature, the resulting gel was dried at $110{ }^{\circ} \mathrm{C}$ for $12 \mathrm{~h}$ followed by calcination at $600{ }^{\circ} \mathrm{C}$ for $2 \mathrm{~h}$.

Synthesis of nano-sized $\mathrm{ZnO}$. Nano-structured $\mathrm{ZnO}$ has been prepared by one step sol-gel technique [47]. In a typical procedure, mixtures of ethanol, diethanolamine (DEA) and zinc acetate dihydrate, were prepared. The concentration of zinc acetate dihydrate in solvent was 0.2 $\mathrm{M}$. The molar ratio of zinc acetate dehydrate and diethanolamine was 1.0. $\mathrm{pH}$ of the mixture was reached to about 9 and then to 11 . The resultant solution was then transferred into a Teflon-lined stainless steel autoclave which was sealed and maintained at $130{ }^{\circ} \mathrm{C}$ for $24 \mathrm{~h}$.

Synthesis of nano- $\gamma-\mathrm{Al}_{2} \mathrm{O}_{3}$ catalyst. The nano- $\gamma-\mathrm{Al}_{2} \mathrm{O}_{3}$ was prepared by sol-gel method according to a procedure described [40]. In a typical experiment, aluminum nitrate (15.614 g) was added to $400 \mathrm{~mL}$ of deionized water. Similarly solution of sodium carbonate was prepared by dissolving (7.95 g) in $400 \mathrm{~mL}$ of deionized water. $200 \mathrm{~mL}$ of deionized water was taken in a $2 \mathrm{~L}$ capacity round-bottom flask and stirred well using magnetic stirrer. Then sodium carbonate and aluminum nitrate solutions were added to $200 \mathrm{~mL}$ of deionized water drop wise. The temperature was maintained $70{ }^{\circ} \mathrm{C}$ during experiment. The $\mathrm{pH}$ after precipitation was found to be in the range of 7.5-8.5. The mixture was stirred for $4 \mathrm{~h}$. The digested precipitates were filtered and re-dispersed again in hot $2 \mathrm{~L}$ of deionized water and air dried at room temperature. The dried precipitates were calcined in a furnace at $550{ }^{\circ} \mathrm{C}$ for $5 \mathrm{~h}$ to produce nano-sized $\gamma$ $\mathrm{Al}_{2} \mathrm{O}_{3}$ powders.

Synthesis of nano-ZSM-5. For synthesis of nano-ZSM-5, tetrapropyl ammonium hydroxide and tetra ethyl ortho silicate were the sources of aluminum and silicon, respectively. Nano-ZSM-5 zeolite was synthesized according to the procedure described earlier [48]. After adding all the ingredients the solution was left to hydrolyze at room temperature for $48 \mathrm{~h}$. The obtained solution was charged into a Teflon-lined stainless-steel autoclave under pressure and static conditions at $170{ }^{\circ} \mathrm{C}$ for of $48 \mathrm{~h}$. The solid phase obtained was filtered, washed with distilled water several times, dried at $120^{\circ} \mathrm{C}$ and then calcined at $550{ }^{\circ} \mathrm{C}$ for $12 \mathrm{~h}$.

\section{Characterization}

$\mathrm{X}$-Ray diffraction pattern were recorded on diffractometer (Philips X'pert) using $\mathrm{CuK} \alpha$ radiation $(\lambda=1.5405 \AA)$. Crystallite size of the crystalline phase was determined from the peak of maximum intensity by using Scherrer formula [46], with a shape factor (K) of 0.9 , as below: crystallite size $=\mathrm{K} \cdot \lambda / \mathrm{W} \cdot \cos \theta$, where, $\mathrm{W}=\mathrm{W}_{\mathrm{b}}-\mathrm{W}_{\mathrm{s}}$ and $\mathrm{W}_{\mathrm{b}}$ is the broadened profile width of experimental sample and $\mathrm{W}_{\mathrm{s}}$ is the standard profile width of reference silicon sample. FT-IR 
spectra of the catalysts were recorded by FT-IR spectrophotometer in the range of 400-4000 $\mathrm{cm}^{-1}$ with a resolution of $4 \mathrm{~cm}^{-1}$ by mixing the sample with $\mathrm{KBr}$. Specific surface area, pore volume and pore size distribution of samples calcined at $600{ }^{\circ} \mathrm{C}$ were determined from $\mathrm{N}_{2}$ adsorption-desorption isotherms at $77 \mathrm{~K}$ (ASAP 2010 Micromeritics). Surface area was calculated by using BET equation; pore volume and pore size distribution were calculated by $\mathrm{BJH}$ method [50]. The samples were degassed under vacuum at $120{ }^{\circ} \mathrm{C}$ for $4 \mathrm{~h}$, prior to adsorption measurement to evacuate the physisorbed moisture. The detailed imaging information about the morphology and surface texture of the catalyst was provided by SEM (Philips XL30 ESEM TMP), a part of the spectra data has been published in our previous work [43].

X-Ray diffraction pattern of sulfated zirconia samples, after calcination at $600{ }^{\circ} \mathrm{C}$, showed the presence of only tetragonal phase with $2 \theta=30.2,50.2$ and 60.2 in sulfated zirconia samples. The FT-IR-spectrum sulfated zirconia samples showed the IR bands of the $\mathrm{SO}_{4}{ }^{2-}$ group in the region of 1240-900 $\mathrm{cm}^{-1}$, with peaks sulfate at 1238, 1145, 1072, 1043 and $996 \mathrm{~cm}^{-1}$, which are attributed to asymmetric and symmetric stretching frequencies $\mathrm{S}-\mathrm{O}$ bond.

The bulk sulfur (wt.\%) retained in sulfated zirconia samples before and after calcination at $600{ }^{\circ} \mathrm{C}$ was analyzed by $\mathrm{C} \mathrm{H} \mathrm{N} \mathrm{S} / \mathrm{O}$ elemental analyzer.

Figure 3 indicates the formation of crystallized alumina, as broad peaks indexed for $\gamma-\mathrm{Al}_{2} \mathrm{O}_{3}$ are seen in the XRD pattern. The broadening of the XRD peaks revealed the nano-size nature of $\gamma-\mathrm{Al}_{2} \mathrm{O}_{3}$ particles in alumina samples.

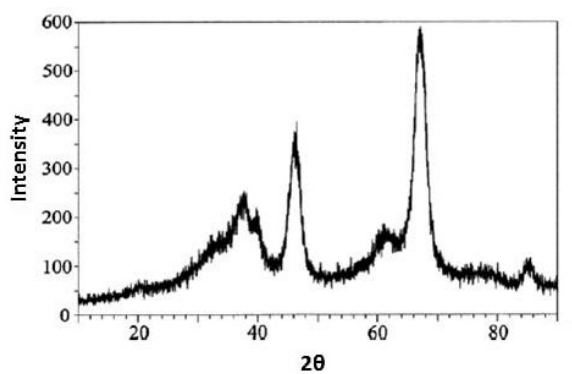

Figure 3. XRD pattern of nano- $\gamma$-alumina catalyst.

The FT-IR spectra of alumina samples calcined at $550{ }^{\circ} \mathrm{C}$ (Figure 4) showed an intense band centered around $3500 \mathrm{~cm}^{-1}$ and a broad band at $1650 \mathrm{~cm}^{-1}$, these are assigned to stretching and bending modes of adsorbed water. The Al-O-Al bending stretching vibrations observed at around $1150 \mathrm{~cm}^{-1}$ are due to symmetric and asymmetric bending modes, respectively. The $\mathrm{OH}$ torsional mode observed at $800 \mathrm{~cm}^{-1}$ overlaps with $\mathrm{Al}-\mathrm{O}$ stretching vibrations. The weak band at $2091 \mathrm{~cm}^{-1}$ is assigned to a combination band. The bands observed at 617 and $481 \mathrm{~cm}^{-1}$ are attributable to stretching and bending modes of $\mathrm{AlO}_{6}$ [51].

The XRD patterns of the synthesized nano-ZSM-5 show the crystallization of structures. The degree of crystallinity was determined from the peak area between $2 \theta=20-24$. Temperature programmed desorption of ammonia was carried out to determine the amount of acid sites relative to reference samples of zeolite with known $\mathrm{Si} / \mathrm{Al}$ ratios. The XRD patterns of nano-sized $\mathrm{ZnO}$ particles obtained. All nano- $\mathrm{ZnO}$ samples exhibited a hexagonal structure. Characteristic peaks of $\mathrm{ZnO}$ appeared at 31.7, 34.5, 36.2 and 56.5 (Figure 5). 


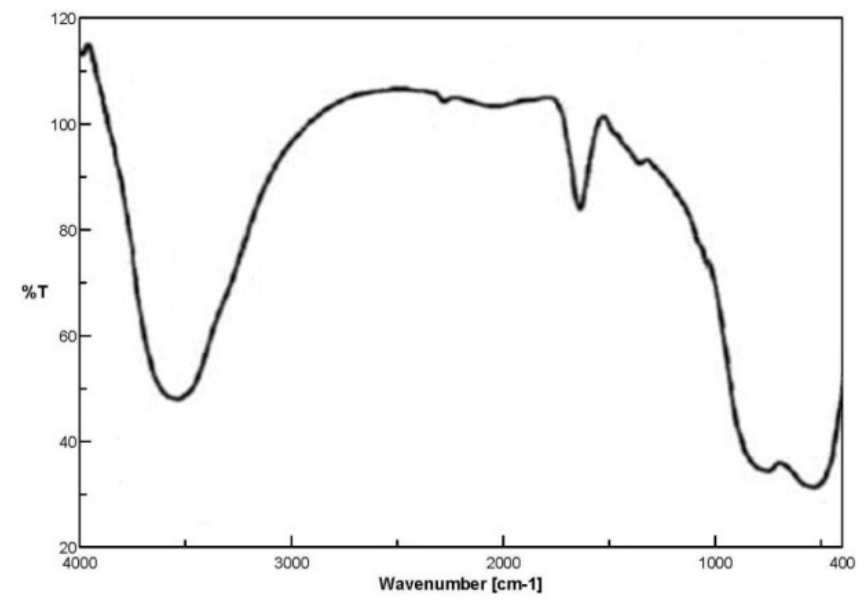

Figure 4. FT-IR spectra nano- $\gamma$-alumina catalyst.

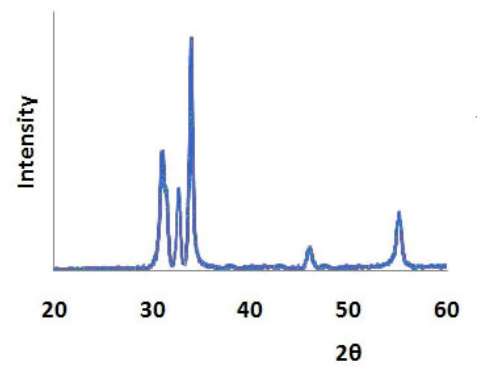

Figure 5. XRD pattern of nano-ZnO catalyst.

General procedure for the synthesis of 1,4-dihydropyridines derivatives

To a mixture of ethyl acetoacetate $(2 \mathrm{mmol})$, corresponding aldehyde $(1 \mathrm{mmol}), \mathrm{NH}_{4} \mathrm{OAc}(1.5$ $\mathrm{mmol})$ in ethanol $(10 \mathrm{~mL})$, catalyst $(25 \mathrm{mg})$ was added and the solution was stirred for appropriate time (Table 3). After completion of the reaction as indicated by TLC, ethyl acetate was added to the solidified mixture and the insoluble catalyst was separated by filtration. The organic layer was dried over with anhydrous sodium sulfate and concentrated in vacuo. The crude were purified by column chromatography using silica gel and eluted with ethyl acetate cyclohexane (3:7) to afford 1,4-DHPs derivatives.

Diethyl-2,6-dimethyl-4-phenyl-1,4-dihydropyridine-3,5-dicarboxylate (1a). M.p.: $150-152{ }^{\circ} \mathrm{C}$. FTIR (KBr) $\left(v_{\max }, \mathrm{cm}^{-1}\right): 3322,2975,1676,1123,1026 \mathrm{~cm}^{-1} .{ }^{1} \mathrm{H}$ NMR (400 MHz, DMSO-d 6 ): $\delta_{\mathrm{H}}: 1.14\left(\mathrm{t}, 6 \mathrm{H}, 2 \mathrm{CH}_{2} \mathrm{CH}_{3}\right) ; 2.23(\mathrm{~s}, 1 \mathrm{H}, \mathrm{pyr}-\mathrm{H}) ; 2.33\left(\mathrm{~s}, 6 \mathrm{H}, \mathrm{pyr}-\mathrm{CH}_{3}\right) ; 4.08\left(\mathrm{q}, 4 \mathrm{H}, 2 \mathrm{CH}_{2} \mathrm{CH}_{3}\right)$; $5.47(\mathrm{~s}, 1 \mathrm{H}, \mathrm{NH}) ; 7.20-7.35(\mathrm{~m}, 5 \mathrm{H}, \mathrm{ArH})$. MS (m/z): $329.16\left(\mathrm{M}^{+}\right)$. Anal. calcd for $\mathrm{C}_{19} \mathrm{H}_{23} \mathrm{NO}_{4}$ : C, 69.28; H, 7.04; N, 4.25. Found: C, 69.04; H, 6.78; N, 3.96.

Diethyl-2,6-dimethyl-(4-chloro-phenyl)-1,4-dihydropyridine-3,5-dicarboxylate (1b). M.p.: 142$144{ }^{\circ} \mathrm{C}$. FTIR $(\mathrm{KBr})\left(v_{\max }, \mathrm{cm}^{-1}\right): 3320,2978,1686,1646,1121,1023,757 \mathrm{~cm}^{-1} .{ }^{1} \mathrm{H}$ NMR $(400$ MHz, DMSO-d6): $\delta_{\mathrm{H}}: 1.18\left(\mathrm{t}, 6 \mathrm{H}, 2 \mathrm{CH}_{2} \mathrm{CH}_{3}\right), 2.21$ (s, 1H, pyr-H), 2.31 (s, 6H, pyr- $\mathrm{CH}_{3}$ ), 4.10 
(q, $\left.4 \mathrm{H}, 2 \mathrm{CH}_{2} \mathrm{CH}_{3}\right), 5.51(\mathrm{~s}, 1 \mathrm{H}, \mathrm{NH}), 7.16-7.27(\mathrm{~m}, 4 \mathrm{H}, \mathrm{ArH}) ; \mathrm{MS}(\mathrm{m} / \mathrm{z}): 363.12\left(\mathrm{M}^{+}\right)$. Anal. calcd for $\mathrm{C}_{19} \mathrm{H}_{22} \mathrm{NO}_{4} \mathrm{Cl}$ : C, 62.72; H, 6.09; N, 3.85. Found: C, 62.54; H, 5.81; N, 3.42.

Diethyl-2,6-dimethyl-(4-nitro-phenyl)-1,4-dihydropyridine-3,5-dicarboxylate (1c). M.p.: 164$166{ }^{\circ} \mathrm{C}$. FTIR $(\mathrm{KBr})\left(v_{\max }, \mathrm{cm}^{-1}\right): 3423,1710,1636,1432,1137,803 \mathrm{~cm}^{-1} .{ }^{1} \mathrm{H}$ NMR $(400 \mathrm{MHz}$, DMSO-d $\left.{ }_{6}\right): \delta_{\mathrm{H}}: 1.16\left(\mathrm{t}, 6 \mathrm{H}, 2 \mathrm{CH}_{2} \mathrm{CH}_{3}\right), 2.23(\mathrm{~s}, 1 \mathrm{H}, \mathrm{pyr}-\mathrm{H}), 2.30\left(\mathrm{~s}, 6 \mathrm{H}, \mathrm{pyr}-\mathrm{CH}_{3}\right), 4.06(\mathrm{q}, 4 \mathrm{H}$ $\left.2 \mathrm{CH}_{2} \mathrm{CH}_{3}\right), 5.56(\mathrm{~s}, 1 \mathrm{H}, \mathrm{NH}), 8.07-7.34(\mathrm{~m}, 4 \mathrm{H}, \mathrm{ArH}) ; \mathrm{MS}(\mathrm{m} / \mathrm{z}): 374.15\left(\mathrm{M}^{+}\right)$. Anal. calcd for $\mathrm{C}_{19} \mathrm{H}_{22} \mathrm{~N}_{2} \mathrm{O}_{6}: \mathrm{C}, 60.95 ; \mathrm{H}, 5.92 ; \mathrm{N}, 7.48$. Found: $\mathrm{C}, 60.86 ; \mathrm{H}, 5.71 ; \mathrm{N}, 7.32$.

Diethyl-2,6-dimethyl-(4-hydroxy-phenyl)-1,4-dihydropyridine-3,5-dicarboxylate $\quad(\mathbf{I d}) . \quad$ M.p.: 226-228 ${ }^{\circ} \mathrm{C}$. FTIR (KBr) $\left(v_{\max }, \mathrm{cm}^{-1}\right): 3336,2978,1682,1126,1022 \mathrm{~cm}^{-1} .{ }^{1} \mathrm{H}$ NMR (400 MHz, DMSO-d $\left.{ }_{6}\right): \delta_{\mathrm{H}}: 1.14\left(\mathrm{t}, 6 \mathrm{H}, 2 \mathrm{CH}_{2} \mathrm{CH}_{3}\right), 2.24(\mathrm{~s}, 1 \mathrm{H}, \mathrm{pyr}-\mathrm{H}), 2.36\left(\mathrm{~s}, 6 \mathrm{H}, \mathrm{pyr}-\mathrm{CH}_{3}\right), 4.08(\mathrm{q}, 4 \mathrm{H}$ $\left.2 \mathrm{CH}_{2} \mathrm{CH}_{3}\right), 5.52(\mathrm{~s}, 1 \mathrm{H}, \mathrm{NH}), 5.26(\mathrm{~s}, 1 \mathrm{H}, \mathrm{OH}), 7.18-7.30(\mathrm{~m}, 4 \mathrm{H}, \mathrm{ArH}) ; \mathrm{MS}(\mathrm{m} / \mathrm{z}): 345.16$ $\left(\mathrm{M}^{+}\right)$. Anal. calcd for $\mathrm{C}_{19} \mathrm{H}_{23} \mathrm{NO}_{5}: \mathrm{C}, 66.06 ; \mathrm{H}, 6.71 ; \mathrm{N}, 4.06$. Found: $\mathrm{C}, 65.83 ; \mathrm{H}, 6.57 ; \mathrm{N}, 3.88$.

Diethyl-2,6-dimethyl-(4-methyl-phenyl)-1,4-dihydropyridine-3,5-dicarboxylate (1e). M.p.: 162$164{ }^{\circ} \mathrm{C}$. FTIR $(\mathrm{KBr})\left(v_{\max }, \mathrm{cm}^{-1}\right): 3326,, 2971,1685,1120,1023 \mathrm{~cm}^{-1} .{ }^{1} \mathrm{H}$ NMR $(400 \mathrm{MHz}$, DMSO-d $\left.{ }_{6}\right): \delta_{\mathrm{H}}: 1.12\left(\mathrm{t}, 6 \mathrm{H}, 2 \mathrm{CH}_{2} \mathrm{CH}_{3}\right), 2.20(\mathrm{~s}, 1 \mathrm{H}, \mathrm{pyr}-\mathrm{H}), 2.31\left(\mathrm{~s}, 6 \mathrm{H}, \mathrm{pyr}-\mathrm{CH}_{3}\right), 2.34(\mathrm{~s}, 3 \mathrm{H}$, $\mathrm{CH}_{3}$ ), 4.02 (q, 4H $\left.2 \mathrm{CH}_{2} \mathrm{CH}_{3}\right), 5.54(\mathrm{~s}, 1 \mathrm{H}, \mathrm{NH}), 7.11-7.32(\mathrm{~m}, 4 \mathrm{H}, \mathrm{ArH}) ; \mathrm{MS}(\mathrm{m} / \mathrm{z}): 343.18$ $\left(\mathrm{M}^{+}\right)$. Anal. calcd for $\mathrm{C}_{20} \mathrm{H}_{25} \mathrm{NO}_{4}: \mathrm{C}, 69.95 ; \mathrm{H}, 7.34 ; \mathrm{N}, 4.08$. Found: $\mathrm{C}, 69.74 ; \mathrm{H}, 6.06 ; \mathrm{N}, 3.82$.

Diethyl-2,6-dimethyl-(4-methoxy-phenyl)-1,4-dihydropyridine-3,5-dicarboxylate (1f). M.p.: $152-154{ }^{\circ} \mathrm{C}$. FTIR $(\mathrm{KBr})\left(v_{\max }, \mathrm{cm}^{-1}\right): 3363,2965,1665,1121,1021 \mathrm{~cm}^{-1} .{ }^{1} \mathrm{H}$ NMR $(400 \mathrm{MHz}$, DMSO-d $\left.{ }_{6}\right): \delta_{\mathrm{H}}: 1.14\left(\mathrm{t}, 6 \mathrm{H}, 2 \mathrm{CH}_{2} \mathrm{CH}_{3}\right), 2.22(\mathrm{~s}, 1 \mathrm{H}, \mathrm{pyr}-\mathrm{H}), 2.28\left(\mathrm{~s}, 6 \mathrm{H}\right.$, pyr- $\left.\mathrm{CH}_{3}\right), 3.64(\mathrm{~s}, 3 \mathrm{H}$, $\left.\mathrm{CH}_{3}\right), 4.06\left(\mathrm{q}, 4 \mathrm{H} 2 \mathrm{CH}_{2} \mathrm{CH}_{3}\right), 5.66(\mathrm{~s}, 1 \mathrm{H}, \mathrm{NH}), 6.75-7.18(\mathrm{~m}, 4 \mathrm{H}, \mathrm{ArH}) ; \mathrm{MS}(\mathrm{m} / \mathrm{z}): 395.17$ $\left(\mathrm{M}^{+}\right)$. Anal. calcd for $\mathrm{C}_{20} \mathrm{H}_{25} \mathrm{NO}_{5}: \mathrm{C}, 66.83 ; \mathrm{H}, 7.01 ; \mathrm{N}, 3.90$. Found: $\mathrm{C}, 66.60 ; \mathrm{H}, 6.83 ; \mathrm{N}, 3.75$.

Diethyl-2,6-dimethyl-(3-nitro-phenyl)-1,4-dihydropyridine-3,5-dicarboxylate (1g). M.p.: 164$166{ }^{\circ} \mathrm{C}$. FTIR $(\mathrm{KBr})\left(v_{\max }, \mathrm{cm}^{-1}\right): 3332,1701,1538,1342,1119,1026 \mathrm{~cm}^{-1}$. ${ }^{1} \mathrm{H}$ NMR $(400 \mathrm{MHz}$, DMSO-d $\left.{ }_{6}\right): \delta_{\mathrm{H}}: 1.21\left(\mathrm{t}, 6 \mathrm{H}, 2 \mathrm{CH}_{2} \mathrm{CH}_{3}\right), 2.43\left(\mathrm{~s}, 6 \mathrm{H}, \mathrm{pyr}-\mathrm{CH}_{3}\right), 4.01-4.16\left(\mathrm{q}, 4 \mathrm{H} 2 \mathrm{CH}_{2} \mathrm{CH}_{3}\right), 5.09$ (s, 1H, pyr-H), $5.65(\mathrm{~s}, 1 \mathrm{H}, \mathrm{NH}), 7.36-8.12(\mathrm{~m}, 4 \mathrm{H}, \mathrm{ArH}))$; $\mathrm{MS}(\mathrm{m} / \mathrm{z}): 374.15\left(\mathrm{M}^{+}\right)$. Anal. calcd for $\mathrm{C}_{19} \mathrm{H}_{22} \mathrm{~N}_{2} \mathrm{O}_{6}: \mathrm{C}, 60.95 ; \mathrm{H}, 6.92 ; \mathrm{N}, 7.48$. Found: $\mathrm{C}, 60.76 ; \mathrm{H}, 6.85 ; \mathrm{N}, 7.36$.

Diethyl-2,6-dimethyl-(3-hydroxy-phenyl)-1,4-dihydropyridine-3,5-dicarboxylate (1h). M.p.: $178-180{ }^{\circ} \mathrm{C}$. FTIR $(\mathrm{KBr})\left(v_{\max }, \mathrm{cm}^{-1}\right): 3341,2971,1686,1121,1020 \mathrm{~cm}^{-1} .{ }^{1} \mathrm{H}$ NMR $(400 \mathrm{MHz}$, DMSO-d $\left.{ }_{6}\right): \delta_{\mathrm{H}}: 1.23\left(\mathrm{t}, 6 \mathrm{H}, 2 \mathrm{CH}_{2} \mathrm{CH}_{3}\right), 2.29\left(\mathrm{~s}, 6 \mathrm{H}, \mathrm{pyr}-\mathrm{CH}_{3}\right), 4.05-4.14$ (q, $\left.4 \mathrm{H} 2 \mathrm{CH}_{2} \mathrm{CH}_{3}\right), 5.07$ (s, 1H, pyr-H), $5.17(\mathrm{~s}, 1 \mathrm{H}, \mathrm{OH}), 5.63(\mathrm{~s}, 1 \mathrm{H}, \mathrm{NH}), 6.60-7.06(\mathrm{~m}, 4 \mathrm{H}, \mathrm{ArH})) ; \mathrm{MS}(\mathrm{m} / \mathrm{z}): 345.16$ $\left(\mathrm{M}^{+}\right)$. Anal. calcd for $\mathrm{C}_{19} \mathrm{H}_{23} \mathrm{NO}_{5}: \mathrm{C}, 66.07 ; \mathrm{H}, 6.71 ; \mathrm{N}, 4.06$. Found: $\mathrm{C}, 65.86 ; \mathrm{H}, 6.55 ; \mathrm{N}, 3.88$.

Diethyl-2,6-dimethyl-(2-chloro-phenyl)-1,4-dihydropyridine-3,5-dicarboxylate (1i). m.p.: 80-82 ${ }^{\circ} \mathrm{C}$. FTIR $(\mathrm{KBr})\left(v_{\max }, \mathrm{cm}^{-1}\right): 3325,2983,1693,1641,1123,1027 \mathrm{~cm}^{-1} .{ }^{1} \mathrm{H}$ NMR $(400 \mathrm{MHz}$, DMSO-d6): $\delta_{\mathrm{H}}: 1.18\left(\mathrm{t}, 6 \mathrm{H}, 2 \mathrm{CH}_{2} \mathrm{CH}_{3}\right), 2.30\left(\mathrm{~s}, 6 \mathrm{H}, \mathrm{pyr}-\mathrm{CH}_{3}\right), 4.08$ (q, $\left.4 \mathrm{H}_{2} \mathrm{CH}_{2} \mathrm{CH}_{3}\right), 4.23$ (s, $1 \mathrm{H}$, pyr-H), 5.58 (s, 1H, NH), $6.05(\mathrm{q}, 1 \mathrm{H}$, pyr-H), 7.17-7.40 (m, 4H, ArH); MS (m/z): 363.12 $\left(\mathrm{M}^{+}\right)$. Anal. calcd for $\mathrm{C}_{19} \mathrm{H}_{22} \mathrm{ClNO}_{4}$ : C, 62.72; H, 6.09; N, 3.85. Found: C, 62.66; H, 6.03; N, 3.71 .

Diethyl-2,6-dimethyl-(4-bromo-phenyl)-1,4-dihydropyridine-3,5-dicarboxylate (1j). M.p.: 158$160{ }^{\circ} \mathrm{C}$. FTIR $(\mathrm{KBr})\left(v_{\max }, \mathrm{cm}^{-1}\right): 3338,2983,1696,1640,1127,1025 \mathrm{~cm}^{-1}$. ${ }^{1} \mathrm{H}$ NMR $(400 \mathrm{MHz}$, DMSO-d $\left.{ }_{6}\right): \delta_{\mathrm{H}}: 1.20\left(\mathrm{t}, 6 \mathrm{H}, 2 \mathrm{CH}_{2} \mathrm{CH}_{3}\right), 2.25\left(\mathrm{~s}, 6 \mathrm{H}, \mathrm{pyr}-\mathrm{CH}_{3}\right), 4.03\left(\mathrm{q}, 4 \mathrm{H} 2 \mathrm{CH}_{2} \mathrm{CH}_{3}\right), 4.93(\mathrm{~s}$, 
$1 \mathrm{H}$, pyr-H), $6.40(\mathrm{~s}, 1 \mathrm{H}, \mathrm{NH}), 7.13-7.30(\mathrm{~m}, 4 \mathrm{H}, \mathrm{ArH})$; MS (m/z): $407.16\left(\mathrm{M}^{+}\right)$. Anal. calcd for $\mathrm{C}_{19} \mathrm{H}_{22} \mathrm{BrNO}_{4}$ : C, 55.89; H, 5.43; N, 3.43. Found: C, 55.80; H, 5.75; N, 3.33.

\section{ACKNOWLEDGEMENTS}

Supports from the Payame Noor University in Isfahan Research Council and helps of Isfahan University of Technology are gratefully acknowledged. Thanks are also due to Mrs. Shahraki and Mr. Narimani for recording the FT-IR spectra of the compound.

\section{REFERENCES}

1. Reddy, G.M.; Shiradkar, M.; Chakravarthy, A.K. Curr. Org. Chem. 2007, 11, 484.

2. Gordeev, M.F.; Patel, D.V.; Gordon, E.M. J. Org. Chem. 1996, 61, 924.

3. Bocker, R.H.; Guengerich, E.P. J. Med. Chem. 1986, 29, 1596.

4. Boschi, D.; Caron, G.; Visentin, S.; Di Stilo, A.; Rolando, B.; Fruttero, R.; Gasco, A. Pharm. Res. 2001, 18, 987.

5. Xie, K.; Liu, Y.-C.; Cui, Y.; Wang, J.-G.; Fu, Y.; Mak, T.C.W. Molecules 2007, 12, 415. 6.

6. Kappe, C.O.; Fabian, W.M.F.; Semones, M.A. Tetrahedron 1997, 53, 2803.

7. Aouam, K.; Berdeaux, A. Therapie 2003, 58, 333.

8. Hilgeroth, A. Mini-Rev. Med. Chem. 2002, 2, 235.

9. Hilgeroth, A.; Lilie, H. Eur. J. Med. Chem. 2003, 38, 495.

10. Litvic, M.; Cepanec, I.; Filipan, M.; Kos, K.; Bartolincic, A.; Druskovic, V.; Tibi, M.M.; Vinkovic, V. Heterocycles 2005, 65, 23.

11. Bretzel, R.G.; Bollen, C.C.; Maeser, E.; Federlin, K.F. Drugs Fut. 1992, 17, 465.

12. Boer, R.; Gekeler, V. Drugs Fut. 1995, 20, 499.

13. Dondoni, A.; Massi, A.; Minghini, E.; Bertolasi, V. Tetrahedron 2004, 60, 2311.

14. Hantzsch, A. Justus Liebigs Ann. Chem. 1882, 215, 1.

15. Love, B.; Sander, K.M. J. Org. Chem. 1965, 30, 1914.

16. Agarwal, A.; Chauhan, P.M.S. Tetrahedron Lett. 2005, 46, 1345.

17. Jahanbin, B.; Davoodnia, A. Behmadi, H.; Tavakoli-Hoseini, N. Bull. Korean Chem. Soc. 2012, 33, 2140.

18. Tewari, N.; Dwivedi, N.; Tripathi, R.P. Tetrahedron Lett. 2004, 45, 9011.

19. Adharvana Chari, M.; Syamasundar, K. Catal. Commun. 2005, 6, 624.

20. Sharma, S.D.; Hazarika, P. Catal. Commun. 2008, 9, 709.

21. Sabitha, G.; Kumar Reddy, G.S.K.; Reddy, C.S.; Yadav, J.S. Tetrahedron Lett. 2003, 44, 4129.

22. Debache, A.; Ghalem, W.; Boulcina, R. Tetrahedron Lett. 2009, 50, 5248.

23. Babu, G.; Perumal, P. T. Aldrichim. Acta 2000, 16.

24. Ko, S.; Sastry, M.N.V.; Lin, C.; Yao, C.F. Tetrahedron Lett. 2005, 46, 5771.

25. Safari, J.; Banitaba, S.H.; Khalili, Sh.D. J. Mol. Catal. A: Chemical 2011, 335, 46.

26. Arsalan, M.; Faydali, C.; Zengin, M.; Kuc, M.; Islamoglu, U.; Irhan, H.D. Turk. J. Chem. 2009, 33, 769.

27. Maheswara, M.; Siddaiah, V.; Rao, Y.K.; Tzeng, Y.M.; Sridhar, C. J. Mol. Catal. 2006, 260, 179.

28. Wang, L.M.; Sheng, J.; Zhang, L.; Han, J.W.; Fan, Z.; Tian, H.; Qian, C.T. Tetrahedron 2005, 61, 1539.

29. Adibi, H.; Samimi, H.A.; Beygzadeh, M. Catal. Commun. 2007, 8, 2119. 
30. Lakshmikantam, M.; Ramani, T.; Chakrapani, L.; Choudary, B.M. Catal. Commun. 2009, 10,370 .

31. Lakshmikantam, M.; Mahendar, K.; Bhargava, S. J. Chem. Sci. 2010, 122, 63.

32. Maquestiau, A.; Mayence, A.; Eynde, J.J. Vanden Tetrahedron Lett. 1991, 32, 3839.

33. Rafiee, E.; Eavani, S.; Rashidzadeh, S.; Joshaghani, M. Inorg. Chim. Acta 2009, 362, 3555.

34. Tamaddon, F.; Razmi, Z.; Jafari, A.A. Tetrahedron Lett. 2010, 51, 1187.

35. Kuraitheerthakumaran, A.; Pazhamalai, S.; Gopalakrishnan, M. Chin. Chem. Lett. 2011, 22, 1199.

36. Ramchander, J.; Raju, G.; Rameshwar, N.; Reddy, T.S.; Reddy, A.R. Spectrochim. Acta Part A 2012, 85, 210.

37. Datta, B.; Pasha M. Afzal, Chin. J. Catal. 2011, 32, 1180.

38. Asl, S.K.; Sadrnezhaad, S.K.; Kianpour rad, M. Mater. Lett. 2010, 64, 1935.

39. Indovina, V.; Pietrogiacomi, D.; Campa, M.C. Appl. Catal. B 2002, 39, 115.

40. Potdar, H.S.; Jun, Ki-Won.; Bae, Jong Wook.; Kim, Seung-Moon.; Lee, Yun-Jo. Appl. Catal A: General 2007, 321, 109.

41. Ni, Y.; Sun, A.; Wu, X.; Hai, G.; Hu, J.; Li, T.; Li, G. Micropor. Mesopor. Mater. 2011, $143,435$.

42. Santor, G.; Maryi, R.; Righi, P. Chem. Ber. 2004, 104, 199.

43. Teimouri, A.; Chermahini, A. J. Mol. Catal. A: Chemical 2011, 346, 39.

44. Kumar, A.; Maurya, R.A. Tetrahedron 2008, 64, 3477.

45. Li, Z.-Y.; Li, J.-T. Ultrasonics Sonochemistry 2007, 14, 677.

46. Tyagi, B.; Mishra, M.K.; Jasra, R.V. Catal. Commun. 2006, 7, 52.

47. Chen, K.J.; Hung, F.Y.; Chang, S.J.; Young, S.J.; Hu, Z.S. Curr. Appl. Phys. 2011, 11, 1243.

48. Firoozi, M.; Baghalha, M.; Asadi, M. Catal. Commun. 2009, 10, 1582.

49. Cullity, B.D.; Stock, S.R. Elements of X-ray Diffraction, 3rd ed., Prentice Hall: Upper Saddle River, New Jersey; 2001; pp. 388.

50. Gregg, S.J.; Sing, K.S.W. Adsorption, Surface Area and Porosity, 2nd ed., Academic Press: New York; 1982.

51. Cross, A.D. An Introduction to Practical IR Spectroscopy, 2nd ed., Butterworth: London; 1964. 